\title{
A Case Study of the Intensive English Program With a Field Trip to the Local Port: The First Year Attempt to Conduct the Program
}

\author{
Yoshihiko Yamamoto, Kazuko Matsuno, Eiji Ugata, Satoru Suto \\ Shizuoka University, Shizuoka, Japan
}

\begin{abstract}
In the English as a foreign language (EFL) environment, EFL teachers often find it difficult for their students to output what they have learned in class after their English classes. The authors of this study work in one of the national universities in Japan and also found it difficult for our students to provide opportunities to use English outside their English classes. Thanks to the local city hall and the local travel agent, the authors of this study managed to conduct a new summer intensive program which included a field trip to the local port. At the local port, our students tried to implement what they had learned on campus and communicate in English with overseas passengers on the cruise ship. The aim of this study is to examine: (1) EFL learners' perception towards the field trip to the local port in this intensive program, (2) whether the intensive program was effective for learners or not, and (3) if there were any issues in conducting the intensive course, how these could be improved. In order to collect the data, a small-scale questionnaire was used for the students who participated in this program and the total of 15 responses were analyzed. The results of this study showed that the field trip was attractive for some participants but not for other participants. Furthermore, the results suggest that although this summer intensive program contributed to encouraging learners' motivation to learn English to some extent, it still needs to be improved for future learners of English.
\end{abstract}

Keywords: EFL, intensive program, field trip, higher education

\section{Introduction}

It is often a challenge for learners of English in the English as a foreign language (EFL) environment to output what they have learned in their English class. Linde (2009), for instance, points out the importance of opportunities for the learners to get both input and practice for what they learned in their classes with the real communication exchange. English is often used as a common language for communication in many places around the world, thus, it is particularly important for university students to gain communication skills in English in order to communicate with people from overseas. According to Japan National Tourism Organization (JNTO) (2016), over 24 million foreign people visited Japan in 2016 while around 17 million Japanese went overseas. It is also important for English teachers in the EFL environment to use the opportunity

Yoshihiko Yamamoto, Ph.D., lecturer, Education Development Center, Shizuoka University.

Kazuko Matsuno, Ph.D., associate professor, Education Development Center, Shizuoka University.

Eiji Ugata, master, associate professor, Student Support Center, Shizuoka University.

Satoru Suto, Ph.D., associate professor, Education Development Center, Shizuoka University. 
to utilize overseas tourists for learners of English. The authors of this study believe that overseas tourists also seek an opportunity to meet the local people and know more about the place where they visit. Indeed, the local travel agent who cooperated with us told us that overseas passengers on the cruise ship asked him to find local people to come with their tours while they stayed in the local city. Overseas passengers enjoyed meeting with local people. This is where the authors of this study started planning the summer intensive English program with a field trip to the local port in 2016. The authors of this study found it difficult for learners of English to be provided with an opportunity to practice what they learn in class after their classes. In the field trip, the authors of this study took students to the local port where foreign cruise ships came in. Thanks to collaboration with the local city hall, local tour guide, and local travel agent, our students were able to host the guests from overseas by using their English. The authors of this study believe that this summer intensive English program is unique and that learners of this program would enjoy the program. This study adopts a case study and the methodology of this study utilizes questionnaires for the participants of the summer intensive program. The next section discusses the issues relating to the EFL learning environment.

\section{Literature Review}

In the EFL circumstance, both learners of English and teachers often face the challenge of how learners of English can practice what they learn outside of their class. There are many past studies examining this issue of providing EFL learners with these opportunities to communicate in English. For example, both Guo (2011) and Zhang (2009) pointed out that learners of their target language in the EFL circumstance often lack an opportunity to be exposed to authentic English. In such environments, the classroom could be the only target language contact for the learners. Rao (2002) found that learners of English in the EFL environment do not need to use what they learn once their classes finish. However, in the ESL environment, learners of English need to use it to survive, which will improve their English proficiency. Field (2007) claimed that learners of ESL acquire information not only in their classrooms, but also outside their classrooms. When learners of their target language are outside, they are often activating and applying what they learnt in their classrooms. Pinner (2013) had found that taking his students on an excursion to interview people on the streets in English made both his students and himself motivated to learn English. Ismail and Tahire (2011) and Fajaira (2013) also pointed out that outdoor activities for EFL learners motivate learners to learn their target language and make the learners enjoy learning their target language. W. V. Wu and P. N. Wu (2008) pointed out that the lack of interaction EFL learners have with native speakers in their daily life is one of the reasons of low English proficiency. They found that countries where English was used as a part of everyday life, such as Singapore, Philippine, or Hong Kong showed higher scores in the international English tests, such as TOEFL or TOEIC than countries where English was not used as a part of everyday life, such as Japan, Thailand, Cambodia, and Taiwan. Merhadad and Ahghar (2013) examined in their study learners' preferences while learning in the EFL context, by collecting questionnaires from EFL students in one of universities in Iran. Firstly, the participants felt that they did not have much opportunity to communicate in English outside the classroom. Secondly, their participants seemed to like learning activities, such as talking with and listening to other students and learning about cultures. Pegrum (2000) explained some reasons of the importance of learning environments outside of the classroom. For instance, learners will encounter authentic language once they go out of their classrooms. Learners can gain practical information, such as how to find where to go, where to buy things, or how much cost things. Exposing learners to authentic language, learners are often motivated to learn their target language. 
As the past studies explained above, in the ESL environment, the authors of this study believe that providing opportunities to learners of English is perhaps not a difficult task. Learners can access plenty of opportunities to output what they learn in their classroom after their classes. However, in the EFL circumstance, the story is different. The authors of this study find it difficult to give opportunities for students to practice what they learn in their class outside their classroom. Therefore, in order to solve this issue, the authors of this study created an intensive English program with a field trip to the local port. The authors of this study believe that EFL learners would have opportunities to practice what they learn in their classroom with some international tourists who speak English during the field trip.

\section{Methodology}

\section{The Intensive English Program}

The intensive English program was held between 16th and 20th, September in 2016. The program ran four days and the additional one-day field trip to the local port where the cruise ship came in. Before the field trip to the local port, students had classes on each day on campus. Class schedule was listed as below.

Table 1

Class Schedule

\begin{tabular}{|l|l|}
\hline Day 1: 1st period & Introduction \& English 1 \\
\hline Day 1: 2nd period & English 2 \\
\hline Day 1: 3rd period & Economy \& industry of the local city \\
\hline Day 1: 4th period & International relationship activities in the local city \\
\hline Day 2: 1st period & About Shizuoka from the foreign point of view \\
\hline Day 2: 2 nd period & English 3 \\
\hline Day 2: 3rd period & Group project \\
\hline Day 2: 4 th period & Group presentation 1 \\
\hline Day 3: 1 st to 4th period & City field work (preparation to the field work to Shimizu port) \\
\hline Day 4: 1 st period & Group discussion 1 \\
\hline Day 4: 2nd period & Group discussion 2 \\
\hline Day 4: 3rd period & Group presentation 2 \\
\hline Optional field trip & At the local port, the field trip \\
\hline
\end{tabular}

The authors of this study invited guest lecturers in this intensive English program. On Day 1, 3rd period, the class was taught by the local chamber of commerce in Japanese and the students learnt about the economy and industry of the local city. On Day 1, 4th period, the class was taught by the local city hall and the students learnt about what their local city did for people from overseas. On Day 2, 1st period, the class was taught by a foreign person who has lived in Japan over 40 years and the students learned how people from overseas see the local area. The authors of this study believed that the lectures given by these guest lecturers were useful for the optional field trip to the local port. We expected our students to use what they learned by these guest lecturers when they communicated with overseas passengers. English lessons were mainly taught by a guest lecturer who had an official license of the tour guide in English and she tried to teach English to the students when they communicated with overseas passengers on the cruise ship. The students in this intensive English program needed to give group presentations twice and took a small quiz for their assessment. Contribution to each class was also a part of their assessment in this class. 


\section{Two Field Trips}

There were two field trips during this intensive English program: the field trip to the local city area and the field trip to the local port when a cruise ship came in. The field trip to the local city was held on Day 3 and this excursion was part of the requirements of the program that our students needed to cover. There were two aims of the field trip to the local city. Firstly, the optional field trip to the port could be canceled depending on the weather. Sometimes, cruise ships could not come to the port when the weather was bad and thus, the authors of this study needed to make a backup plan in case the cruise ship did not come to the port. Secondly, the authors of this study wanted our students to practice how they could explain things in the local area. These local tourist spots are often visited by tourists including domestic and overseas, and our students had a chance to visit these spots again with overseas tourists on the day of the field trip to the port. In the morning, one of the teachers in this program was an English tour guide and she demonstrated how to guide foreigners in English first. Then she let our students practice what they learned within small groups. In the afternoon, the authors of this study let students visit the same area again in groups, without an English tour guide.

The field trip to the local port was an optional activity for our students. If the field trip to the local port was held as a part of requirements for the students and then it was canceled due to the bad weather, the students would miss four lessons worth of the course. It meant that the students would not satisfy one of requirements (students need to participate 15 lessons) to pass this intensive program. Therefore, in order to give final grades of this program to the students, they were required to participate in all 15 lessons excluding the field trip to the local port. Thanks to their cooperation, the local travel agent arranged guided taxi tours for overseas passengers from the ship. Some overseas passengers wanted our students to come with them. There were some reasons for this: Firstly, there are not many taxi drivers who can speak English and it is difficult for both a taxi driver and foreign passengers to communicate with each other. Secondly, whilst there is some demand for professional English tour guides, some foreign passengers prefer to take volunteer students with their taxi tours. Many of the passengers want to enjoy communication with local people and our students match what foreign passengers want. On the day of the field trip on this program, the weather was not good, since a typhoon was approaching Japan. Therefore, some outdoor activities at the local port which were planned by the city council and the port was cancelled. Despite the bad weather conditions on the day of the field trip, we managed to give opportunities for three students to go on a taxi tour with overseas tourists. Also some activities were arranged for the rest of the students to support overseas passengers in English inside one of the buildings.

\section{Data Collection}

Questionnaires were used in this study in order to gather student participants' insights. Since the participants of this study were Japanese university students, all questions were asked in Japanese. An English version of the questionnaire is included below in the Results section. The questionnaires were carried out on 19th of September, 2016 for those who did not come to the field trip and on the 20th of September, 2016 for those who did, with their permission. Fifteen university students completed a questionnaire out of the total 20 students who registered in this intensive program. Out of 15 students, five students came to the field trip on the last day and answered the questionnaire. Fourteen students were first year students and there was only one student who was a second year student.

\section{Participants}

Twenty students in total participated in this English program and all of them scored above TOEIC 600 
scores that was a requirement for students to enroll in the intensive English program. Nineteen students were first-year students and one student was a second-year student. Students belonged to different faculties, such as Agriculture, Education, Engineering, Humanities, and Social Science.

\section{Questionnaires}

All the questions for the participants are listed below. Q 1 to Q 6 and Q 11 were designed for all students who participated in this class and Q 7 to Q 13, except Q 11 and Q 13, were designed for the students who came to the optional field trip to the local port.

1. Do you like English or not?

2. Do you think learning English is useful or not for your future?

3. In Japanese university, an English subject is a compulsory subject in whatever major you are. Do you think it is a good idea or not?

4. Please tell us reasons for both Q 2 and Q 3.

5. Have you experienced study abroad?

6. Please tell us why you took this intensive English class.

7. Were you able to use what you learned in class on the optional field trip at the port?

8. Were you able to communicate with overseas passengers on the cruise ship during the field trip?

9. Please tell us both good and bad things about the optional field trip at the port.

10. On the Day 3 in this intensive class, we went to the local city as the field trip. Was it useful for the optional field trip at the port?

11. In this intensive English class, there were not only English teachers, but also other lecturers, such as people from city hall and the local travel agent. Were their lectures useful for you?

12. For those who participated in the field trip to the local port, what questions did you get from overseas passengers?

13. Please tell us what you think about this intensive English program.

\section{Results}

First of all, results of Q 1, Q 2, Q 3, and Q 5 are shown below.

As Table 2 shows, all participants who answered Q 2 admitted both the importance of learning English at university and that learning English would be useful for their future. Although three participants answered that they did not like English, they admitted both the importance of learning English and the usefulness of learning English for their future.

Secondly, the results of both Q 2 and Q 6 are shown below.

Table 2

The Results of $Q 1, Q 2, Q 3$, and $Q 5$

\begin{tabular}{lcc}
\hline Questions & \multicolumn{2}{c}{ Answers } \\
\cline { 2 - 3 } Q 1: Do you like English or not? & 12 & No \\
Q 2: Do you think learning English is useful or not for your future? & 15 & 3 \\
Q 3: In Japanese university, an English subject is a compulsory subject in whatever & 15 & 0 \\
major you are. Do you think it is a good idea or not? & 2 & 0 \\
Q 5: Have you experienced study abroad? & & 13 \\
\hline
\end{tabular}


Table 3

The Results of Reasons for $Q 2$

\begin{tabular}{|l|l|}
\hline $\begin{array}{l}\text { Numbers of the } \\
\text { answers }\end{array}$ & $\begin{array}{l}\text { Reasons for Q 2 (Do you think learning English is useful or not for your future?) \& Q 3 (In Japanese university, } \\
\text { an English subject is a compulsory subject in whatever major you are. Do you think it is a good idea or not?) }\end{array}$ \\
\hline 10 & English is used as a lingua franca around the world. \\
\hline 4 & I believe English is important for my future job. \\
\hline 1 & More tourists from overseas will come to Japan in the future. \\
\hline 1 & It is better mastering English than having no English skill. \\
\hline
\end{tabular}

Table 4

The Results of Reasons for $Q 6$

\begin{tabular}{|l|l|}
\hline $\begin{array}{l}\text { Numbers of the } \\
\text { answers }\end{array}$ & Reasons for Q 6 (Please tell us why you took this intensive English class.) \\
\hline 6 & To improve my English skill. \\
\hline 6 & The course syllabus attracted me to take this course. \\
\hline 3 & To get credits for my graduation. \\
\hline 1 & I wanted to do something new. \\
\hline 1 & I have nothing to do over the summer. \\
\hline 1 & I am good at English. \\
\hline
\end{tabular}

Table 3 shows the reasons for Q 2. Ten participants answered English was used as a lingua franca around the world and four participants acknowledged the importance of learning English for their future jobs. One participant mentioned the number of overseas tourists in Japan was increasing recently, and thus, admitted the importance of learning English. The last answer was interesting to be seen. The participant answered, "It is better mastering English than having no English skill”. Table 4 shows the reasons for Q 6. There are some positive reasons for taking this intensive program by the participants, such as "To improve my English skill" and "The course syllabus attracted me to take this course". However, the reason "To get credits for my graduation" seems an external motivation by the participants to take this intensive program. As opposed to regular English classes which have 15 weeks per semester, the intensive program ends within four days. Although it is the intensive program, the participants will get two credit points towards their graduation within four days.

The tables below are the results of the participants who participated in the field trip to the local port. In Table 5, the results of Q 7, Q 8, and Q 10 are shown.

As for the results of Q 7, three participants scored lower (2 and 3) and only one participant scored the highest (10). As opposed to Q 7, in Q 8, one participant scored a 2 which is a lower score and three participants scored on average (both 5 and 6). There is one person who scored the highest (10). As for Q 10, only four participants answered. Two participants scored an 8 and one participant scored the lowest.

Table 5

The Results of $Q 7, Q 8$, and $Q 10$

Q 7: Were you able to use what you learnt in class when you participated in the field trip at the local port?

1: Never 10: Very much (10 point scale)

\begin{tabular}{lc}
\hline Numbers of answers & Rates which are given \\
\hline 2 & 2 \\
1 & 3 \\
1 & 8 \\
1 & 10 \\
\hline
\end{tabular}


(Table 5 to be continued)

\begin{tabular}{ll}
\hline Q 8: Were you able to communicate with foreign passengers at the local port? \\
1: Never 10: Very much (10 point scale) & Rates which are given \\
\hline Numbers of answers & 5 \\
\hline 2 & 2 \\
1 & 6 \\
1 & 10 \\
1 & \\
\hline Q 10: On the Day 3, we had the field trip in the local city. Was it useful for you on the second field trip at the local port? \\
1: Never 10: Very much (10 point scale) \\
\hline Numbers of answers & Rates which are given \\
\hline 2 & 8 \\
1 & 4 \\
1 & 1 \\
\hline
\end{tabular}

In Table 6 below, the results of both positive and negative points of Q 9 are shown.

Table 6

The Results of $Q 9$

\begin{tabular}{|l|l|}
\hline Numbers of the answers & $\begin{array}{l}\text { Q } 9 \text { (Please tell us both good and bad things about the optional field trip at the port) } \\
\text { Good points }\end{array}$ \\
\hline 4 & I was able to explain things to foreign passengers in English. \\
\hline 1 & The passengers understood my English. \\
\hline Numbers of the answers & Negative points. \\
\hline 1 & We did not have time to explore around with foreign passengers. \\
\hline 1 & Conversation with foreign passengers did not last long. \\
\hline 1 & I sometimes did not understand what the foreign passengers said to me. \\
\hline 1 & It was difficult for me to know when to start the conversation with foreign passengers. \\
\hline 1 & It was raining on the day and it seemed that everything at the port was disorganized. \\
\hline
\end{tabular}

Table 6 shows the results of both good points and bad points about the field trip to the local port. For the good points, the participants explained that they were able to communicate with passengers from overseas. As for the negative points, three participants mentioned about communication with passengers in English. One participant pointed out the shortage of time to communicate with passengers and one participant said disorganization of the event at the port.

Table 7 shows the results of Q 12. Most questions from the overseas tourists tend to be questions about information of the places where they wanted to go, such as "Where can we catch a taxi?" and "Where is a shuttle bus?". Also, there are some questions about the places where they went, such as "Who built this building?" and "Why are buildings of temples painted as red color?". The question "What do you study at university?" is an interesting question to be discussed later.

Table 8 shows the results of Q 13. Overall, the participants showed positive feedback for this English program. However, some participants pointed that the program focused on a little bit too much on learning how to guide overseas passengers instead of learning communication skills in English. 
Table 7

The Results of $Q 12$

Q 12: For those who participated in the field trip to the local port, what questions did you get from overseas passengers?

How long can we spend here?

Who lived in this building?

What is this?

Where can we catch a taxi?

Teach me how to do it.

How did you come to the local port this morning?

Do you know today's exchange rate?

Where can we try tea ceremony?

Where is a toilet?

What do you study at university?

Where is a shuttle bus?

Does this bus stop at the local station?

Is there any free wifi which I can use?

Why are buildings of temples painted as red color?

Could you please tell us more about dragons?

Where can we buy a backpack since our backpack is broken?

What are these products made of?

Aren't paid for this activity?

Table 8

The Results of $Q 13$

Q 13: Please tell us what you think about this intensive English program.

After this English program finished, I felt like I needed to study English more than ever before. This course gave me a strong motivation to study English from now on. However, I felt like the lecture part of this course was too long. I mean teachers spoke a little bit too long. I wanted to speak more on my own.

The course focused on the field trip to the local port a little bit too much.

I felt that the level of this program was too high for me. In particular, I felt it was difficult for me to take part in discussions in

English since I was not confident of speaking in English.

It was great to have not only an English teacher but also guest lecturers through this course. I learnt a lot about the local city from them. Also I mainly learnt English through both reading and writing so far but in this course, there were a lot of discussions in English which I liked very much.

It was good not only learning English but also learning things about the local city.

I think English is a tool for communication. However, through this English program, I learnt in order to communicate effectively with people, and I need to know things more than ever before. After this English program, I felt like I want to know more about the local city and will research about it more.

I felt like this English program focused on a little bit too much on learning how to guide for overseas passengers in English.

However, through this course, I learnt how to do a presentation and discussions in English which I never experienced to learn. It was a good experience for me to learn both of them.

The field trip to the local port was good. Overseas passengers also nice.

\section{Discussion}

Based on the results of this study, some interesting discussion points are made. In this part, discussions are made based on each aim of this study. First of all, the first research aim, "learners' perception towards the field trip to the local port in this intensive program", is discussed based on the results of this study. As results of Q 6 (Please tell us why you took this intensive English class) showed, the English program including the field trip to the local port tends to be preferred by some participants. For instance, in one of the results of Q 6, six participants in particular, answered as "The course syllabus attracted me to take this course". This answer suggests that the field trip to the local port attracted some participants to this study. On the other hand, there were also three participants who answered "To get credits for my graduation" for Q 6. This answer does not support that the field trip to the local port attracted the participants of this study to take this program. The 
English program was an intensive program which is completed in four days and students can get two credit points towards their graduation. During the semester, a subject is normally completed in 15 weeks and students get either one or two credits. Thus from the point of view of students, the intensive program is attractive to gain credit points within such a short period, compared to the regular class in a regular semester. It would be interesting to examine if the English program was still attractive to students when this English program is held during the regular semester period.

However, although the component of the field trip to the local port attracted some participants, it did not attract others. There were only five students that came to this field trip even through one of the answers ("The course syllabus attracted me to take this course") of Q 6 that was popular among the participants of this study. The authors of this study expected that more participants would have joined in the field trip when they started organizing the field trip. There are some reasons which are considered for this. The first reason is that participation in the field trip to the local port was optional for the students. Thus, the participants of this study do not get any scores towards their final grades on this course whether they came or not. In addition, as one of the reasons ("To get credits for my graduation") for Q 6 showed, some participants of this study possibly were not interested in coming to the field work to the local port. The authors of this study tried to make the field trip a component of the course assessment, but there was a possibility that it could be canceled due to the weather conditions. Thus, the authors of this study finally decided that the field trip should be optional.

Second of all, the second research aim of this study "whether the intensive program was effective for learners or not" is discussed based on the results of this study. Overall, based on the results of Q 7, Q 8, Q 10, and Q 13, the participants positively felt that the intensive program was considered effective to some extent, yet it perhaps needs to be improved in order to satisfy learners' needs for the future. There are both positive and negative feedback towards this intensive English program on the results of Q 7, Q 8, Q 10, and Q 13. As for the positive feedback, for instance, the results of Q 13 were overall positive and for both Q7 and Q8, two participants scored the higher grades. Also in Q 10, some participants positively valued the field trip to the local city. These positive results suggest that the intensive English program was overall successful for some participants. However, there were some negative feedbacks towards this intensive program as well. For instance, some participants pointed out on Q 13, "The course focused on the field trip to the local port a little bit too much" and "This English program focused on a little bit too much on learning how to guide for overseas passengers in English". In addition, some participants gave lower scores towards this intensive English program on both Q 7 and Q 8. These results suggest that the content of the intensive program perhaps needs to be reorganized for the next year. In order to improve the quality of this intensive program, the authors of this study suggest that the contents of the English lessons on campus in particular need a balance between teaching daily communication skills and preparation for the field trip to the port.

Last of all, the third aim of this study "if there are any issues in conducting the intensive course, how could they be improved" is discussed. The issue was raised by a participant, who was seen on the result of Q 9, responding: "It was raining on the day and it seemed that everything at the port was disorganized". As this participant answered, the weather on the day of the field trip to the local port was raining and windy. Since this English program was held for the first time this year, the guided taxi tours were the main activity of the field trip for the students. Although there were only five students that came to the field trip to the port, there were not enough guided taxi tours provided for all of these five students due to the bad weather. Therefore, the local city hall offered the students, who were not able to go to the guided taxi tours, to join the other activities which 
were organized by the local city hall. In order to avoid this issue for the next year, the authors of this study suggest some other activities for the students which could be arranged as well as the guide taxi tours. Depending on the weather conditions, it is unpredictable how many guided tours will be offered to the students. Therefore, activities for the students those are able to communicate with overseas passengers at the local port need to be prepared well in advance. For instance, there was an information desk for overseas passengers at the local port when the cruise ships came in. The students could help and support the information desk to explain things for overseas passengers in English. It is also important to cooperate together among the teachers, the city hall, and the local travel agent before the field trip occurs. Since this English program started this year, it was not easy for all the participants to predict what issues would appear at the field trip.

\section{Conclusion}

In conclusion, this study examined the intensive English program with the field trips where the learners of English could put into practice what they learnt in class. In the EFL environment, learners of English often find themselves able to use their English outside of their classrooms, unlike ESL students. The authors of this study attempted to give their ESL students opportunities to communicate with overseas people in a field trip to the local port. The aims of this study were to explore: (1) learners' perception towards the field trip to the local port in this intensive program, (2) whether the intensive program was effective for learners or not, and (3) if there were any issues in conducting the intensive course, how they could be improved. As for the first aim of this research, this study found that the field trip to the local port was preferred to some extent by the participants of this study. However, the field trip to the local port did not particularly attract some learners of English. This could be due to the field trip being an option for the participants to attend. To find the answer of the second aim of this study "whether the intensive English program was effective for learners or not", this study found the intensive English program was effective for the learners of English to some extent. However, it needs to improve the content of English lessons on campus in particular, requiring a balance between teaching communication skills in English and preparing things for the field trip to the local port. As for the third research aim, this study found the issues on the day of the field trip. Since this intensive program started this year for the first time and the weather of the field trip to the local port was bad, the activities in the local port were disorganized. In order to solve this issue, it is important to cooperate together among the teachers, the city hall, and the local travel agent. Also, the activities of the field trip need to be prepared well in advance. This study was limited by access to only a small number of participants.

\section{References}

Fajaria, I. (January 2013). Outdoor class project: The potential benefits to foster EFL student's language proficiency. Advances in Language and Literary Studies, 4(1), 140-144.

Field, J. (2007). Looking outwards, not inwards. ELT Journal, 61(1), 30-38.

Guo, S. C. (2011). Impact of an out-of-class activity on students' English awareness, vocabulary, and autonomy. Language Education in Asia, 2(2), 246-256.

Ismail, N. S., \& Tahir, I. M (2011). A strategy to enhance students' English proficiency. Studies in Literature and Language, $2(3), 61-72$. Japan National Tourism Organization. (2017). Visitor arrivals, Japanese overseas travelers. Retrieved February 15, 2018, from https://www.jnto.go.jp/jpn/statistics/marketingdata_outbound.pdf

Linde, A. (2009). How polite can you get?: A comparative analysis of interlanguage pragmatic knowledge in Spanish and Moroccan EFL university students. Porta Linguarum: Revista Internacional de didÁctica de Las Lenguas Extranjeras, 12, 133-148. 
Merhadad, A. G., \& Ahghar, M. R. (2013). EFL students' language learning preferences at Islamic Azad University-Hamedan Branch. Procedia-Social and Behavioral Sciences, 93, 102-106.

Pegrum, M. A. (2000). The outside world as an extension of the EFL/ESL classroom. The Internet TESOL Journal, 6(8). Retrieved from http://iteslj.org/Lessons/Pegrum-OutsideWorld.html

Pinner, R. (2013). Authenticity of purpose: CLIL as a way to bring meaning and motivation into EFL contexts. Asian EFL Journal, 15(4), 138-159.

Rao, Z. (2002). Chinese students' perceptions of communicative and non-communicative activities in EFL classroom. System, 30, 85-105.

Wu, W. V., \& Wu, P. N. (2008). Creating an authentic EFL learning environment to enhance student motivation to study English. Asian EFL Journal, 10(4), 211-222.

Zhang, Y. (2009). Reading to speak: Integrating oral communication skills. English Teaching Forum, 47(1), 32-34. US Department of State. Bureau of Educational and Cultural Affairs, Office of English Language Programs, SA-5, 2200 C Street NW 4th Floor, Washington, DC 20037. 